\title{
高温塩化物水溶液中におけるステンレス鋼の孔食に 及ぼす窒素およびモリブデン化学種の影響
}

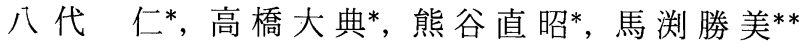 \\ *岩手大学工学部応用分子化学科 \\ ** 株式会社日立製作所日立研究所
}

\section{Effect of Nitrogen and Moribdenum Species on the Pitting of Stainless Steel in High Temperature Chloride Solutions}

\author{
Hitoshi Yashiro*, Daisuke Takahashi*, Naoaki Kumagai* and Katsumi Mabuchi** \\ * Department of Molecular Science and Applied Chemistry, \\ Faculty of Engineering, Iwate University \\ ** Hitachi Research Laboratory, Hitachi Ltd.
}

\begin{abstract}
The effects of alloyed nitrogen and molybdenum on the pitting behavior of austenitic stainless steels were examined comparing with that of corresponding oxyacid salts (i.e. nitrate and molybdate) in a solution. The comparison was made through measurements of pitting potential as a function of temperature up to $423 \mathrm{~K}$ and that of pitting temperature as a function of applied potential. Both alloyed nitrogen and nitrate ion in a solution showed inhibitive effect at lower temperatures rather than at high temperatures. Pitting temperatures measured in a solution containing nitrate showed a unique dependency on potential: the nobler the potential, the higher the pitting temperature. However, it could not be revealed that alloyed nitrogen inhibited pitting through formation of nitrate ion because stainless steels alloyed with nitrogen did not show the similar dependency of pitting temperature on applied potential. Both alloyed molybdenum and molybdate in a solution enhanced pitting potential more effectively at higher temperatures, possibly because the film formation reaction in which molybdenum species involved proceeded more rapidly at higher temperatures. However molybdate ion could miss its distinctive effect at high temperatures when a specimen was polarized before heating. Excellent inhibition of pitting was realized at every temperature when nitrate and molybdate ions were mixed into a chloride solution: nitrate worked at nobler potentials even at lower temperatures and molybdate worked at higher temperatures even at less noble potentials. The stainless steel which contained both nitrogen and molybdenum also showed good performance against chloride solutions, uniting the individual advantages.
\end{abstract}

Key words: pitting, stainless steel, nitrogen, molybdenum, nitrate, molybdate, inhibition, high temperature

\section{1. 緒言}

ステンレス鋼の耐孔食性や耐隙間腐食性を向上させる 目的で, 種々の添加元素の効果が検討されてきた ${ }^{1), 2) 。 ~}$ 代表的な元素のひとつとしてモリブデンが挙げられる。 モリブデンは，SUS 316 ステンレス鋼に代表されるよ

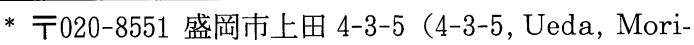
oka, 020-8551 Japan)

** 干319-1292 日立市大みか町 7-1-1（7-1-1, Omikacho, Hitachi, 319-1292 Japan)
うに，固溶元素としても耐局部腐食性の向上に効果があ るが，溶液中にモリブデン酸イオンとして存在させても 類似の局部腐食抑制効果を示す ${ }^{3)}$ 。このように，ある元 素を，鋼中に固溶した場合の作用と，溶液中に酸素酸イ オンとして存在させた場合の作用とを比較すると，その 元素の局部腐食抑制機構に関する知見がより鮮明になる と期待できる。

ところで，ステンレス鋼中に窒素を固溶することで耐 局部腐食性が向上することは，比較的古くから知られて 
いたが，その抑制機構は，今もって明確にされていな (い4),5)。一方, 溶液中に硝酸イオンが存在すると, 耐孔 食性が増加することも古(から知られている ${ }^{6)}$ 。しかし 硝酸イオンの孔食抑制効果には特異な電位依存性があ り, この理由も十分理解されていない7)。固溶窒素の孔 食抑制効果が，モリブデンの場合と同じように，酸素酸 イオン（ここでは硝酸イオン）としての作用と共通して いるという可能性もあるが，実験的な証拠は得られてい ない。

先に著者らは，モリブデン酸イオンと硝酸イオンを含 む複数の酸素酸イオンの, ステンレス鋼の孔食に対する 抑制効果を検討するため， 2 種類の測定 : 1）動電位分 極による孔食電位を温度の関数として $423 \mathrm{~K}$ まで測定す る，2）室温であらかじめ所定電位に分極した後，昇温 することで孔食発生温度を測定する，を比較して行った 結果, 各種酸素酸イオンの孔食抑制作用の特徵をより明 確にすることができた ${ }^{7)}$ 。本研究では，この手法を，窒 素およびモリブデンを固溶したオーステナイトステンレ ス鋼に適用し，溶液中に存在する硝酸イオンおよびモリ ブデン酸イオンの作用と比較することを目的とした。

\section{2. 実験}

\section{1 試 験 片}

（社）腐食防食協会「高窒素ステンレス鋼の耐食性と 材料科学」分科会で作製した共通試料を実験に使用し た。Table 1 に試料の化学組成の分析值を示す。これら は，SUS 304 ステンレス鋼の組成を基準に，窒素を添 加しないものと約 $0.2 \%$ 添加したもの，モリブデンを含 むSUS 316 ステンレス鋼の組成を基準に窒素を添加し ないものと約 $0.2 \%$ 添加したもので, 受け入れのまま, 旗型 ${ }^{8)}$ に切り出し，エメリ一紙＃ 0/6 番まで乾式研磨, アセトン, メタノールの順で超音波洗浄して, 直ちに実 験に用いた。

\section{2 装}

内容積 $300 \mathrm{~cm}^{3}$ の $\mathrm{Ti}$ 製オートクレーブ, 内部型 $\mathrm{Ag} / \mathrm{AgCl} / \mathrm{KCl}\left(0.1 \mathrm{kmol} \mathrm{m}^{-3}\right)$ 参照電極および, 熱 電対挿入管を兼齐た $\mathrm{Pt}$ 対極は, 以前に報告したもの ${ }^{7)}$ を使用した。なお，後述する定電位昇温試験は，内部参 照電極に対して一定電位に保ちながら昇温する試験であ
るため, 標準水素電極電位（SHE）に対する電位が一 定に保たれるわけではない。本論文では, 電位はすべて 内部参照電極に対する電位のまま表示したが, これらの 電位は必要に応じ SHE 基準に換算することができ $ろ^{7)}$ 。

\section{3 操 作}

Table 1 に示した 4 種類のステンレス鋼に対し， 0.1 $\mathrm{kmol} \mathrm{m} \mathrm{m}^{-3} \mathrm{NaCl}$ 溶液中で以下の 2 種類の試験を行っ た。同様の実験を $0.1 \mathrm{kmol} \mathrm{m}^{-3} \mathrm{NaCl}$ 溶液に $\mathrm{NaNO}_{3}$ $\left(0.02 \mathrm{kmol} \mathrm{m}^{-3}\right)$ または $\mathrm{Na}_{2} \mathrm{MoO}_{4}\left(0.02 \mathrm{kmol} \mathrm{m}^{-3}\right)$ を溶解しても行った。

\section{3.1 アノード分極試験}

$\mathrm{Ti}$ 製オートクレーブに $0.1 \mathrm{kmol} \mathrm{m}^{-3} \mathrm{NaCl}$ 溶液 180 $\mathrm{cm}^{3}$ を入れ, $\mathrm{Ag} / \mathrm{AgCl}$ 参照電極および $\mathrm{Pt}$ 対極をセッ 卜後, Arを 2 時間通じて溶存酸素を除去した。オート クレーブを約 1 時間かけて所定温度に昇温し, 自然電位 が安定していることを確認した後, $20 \mathrm{mV} / \mathrm{min}$ の分極 速度でアノード分極した。電流密度が $100 \mu \mathrm{A} / \mathrm{cm}^{2}$ に 達した電位を孔食電位 $\left(V^{\prime}{ }_{\text {pit }}\right)$ とした。

\section{3.2 定電位昇温試験}

前項と同様に電極をセットして $\mathrm{Ar}$ を通じた後, 室温 で自然電位から $100 \mathrm{mV} / \mathrm{min}$ の分極速度で所定電位ま で分極し，1時間保持した。次にオートクレーブをほぼ $1 \mathrm{~K} / \mathrm{min}$ の昇温速度で加熱し, 温度-電流密度曲線を測 定した。電流密度が $100 \mu \mathrm{A} / \mathrm{cm}^{2}$ に達した温度を孔食 温度 $\left(T^{\prime}{ }_{\mathrm{pit}}\right)$ とした。

\section{3. 結果}

\section{1 固溶窒素亡硝酸イオンの作用の比較}

Fig. 1 および 2 は，それぞれ窒素を添加していない SUS 304 ステンレス鋼（以下 304 鋼）と窒素を添加し た SUS 304 ステンレス鋼（以下 $304 \mathrm{~N}$ 鋼）に対し， 298 および $423 \mathrm{~K} の 0.1 \mathrm{kmol} \mathrm{m}^{-3} \mathrm{NaCl}$ 溶液中で測定した アノード分極曲線 (A) と, $298 \mathrm{~K}$ でアノード分極曲線 上に示した各電位（ $\mathrm{a} \sim \mathrm{c})$ に保持し昇温したときの温 度-電流曲線（B）を示している。Fig. 1 より， $V^{\prime}$ pit は 高温で卑になり， $T^{\prime}{ }_{\mathrm{pit}}$ は電位が貴なほど低くなること がわかる。Fig. 2 より, $304 \mathrm{~N}$ 鋼では $V^{\prime}$ pit および $T^{\prime}$ pit が 304 鋼よりやや高くなっており, 耐孔食性が改善さ

Table 1 Chemical composition of specimen. (mass\%)

\begin{tabular}{lcccccccccccc}
\hline & $\mathrm{C}$ & $\mathrm{Si}$ & $\mathrm{Mn}$ & $\mathrm{P}$ & $\mathrm{S}$ & $\mathrm{Ni}$ & $\mathrm{Cr}$ & $\mathrm{Mo}$ & $\mathrm{Al}$ & $\mathrm{Cu}$ & $\mathrm{O}$ & $\mathrm{N}$ \\
\hline 304 & 0.008 & 0.48 & 0.51 & 0.005 & 0.001 & 10.97 & 18.46 & 0.004 & 0.005 & 0.007 & 0.0110 & 0.022 \\
$304 \mathrm{~N}$ & 0.010 & 0.47 & 0.52 & 0.005 & 0.001 & 10.91 & 18.45 & 0.004 & 0.005 & 0.008 & 0.0100 & 0.220 \\
316 & 0.010 & 0.51 & 0.51 & 0.006 & 0.001 & 11.96 & 17.10 & 1.990 & 0.049 & 0.006 & 0.0031 & 0.046 \\
$316 \mathrm{~N}$ & 0.009 & 0.51 & 0.52 & 0.007 & 0.001 & 11.97 & 17.13 & 2.010 & 0.052 & 0.007 & 0.0040 & 0.220 \\
\hline
\end{tabular}



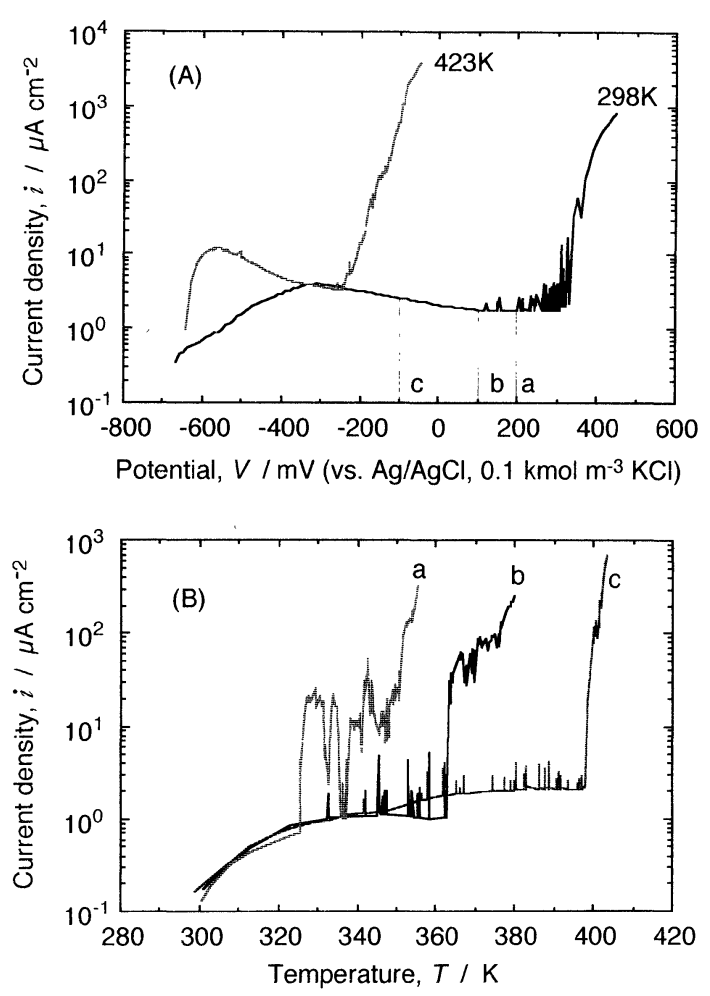

Fig.1 (A) Anodic polarization curves at constant temperatures and (B) current densitytemperature curves at constant potentials (a through c) for 304 specimen in $0.1 \mathrm{kmol}$ $\mathrm{m}^{-3} \mathrm{NaCl}$.

れているといえる。また $V^{\prime}{ }_{\mathrm{pit}}$ の温度依存性や $T^{\prime}{ }_{\mathrm{pit}}$ の 電位依存性はFig. 1 と 2 とでほぼ同様といえる。

Fig. 3 は, 304 鋼に対し, $0.1 \mathrm{kmol} \mathrm{m}^{-3} \mathrm{NaCl}+$ $0.02 \mathrm{kmol} \mathrm{m}^{-3} \mathrm{NaNO}_{3}$ 溶液中で同様の測定を行った 結果を示している。著者らが以前示したように, 硝酸イ オンが存在すると, 高電位での孔食発生が強く抑制され る。この結果, $298 \mathrm{~K}$ (ここでは $0.1 \mathrm{kmol} \mathrm{m}^{-3} \mathrm{NaCl}$ 溶液中での $V^{\prime}$ pit が約 $500 \mathrm{mV}$ ) では非常に貴な孔食電 位を示すのに対し， $423 \mathrm{~K}$ (ここでは $0.1 \mathrm{kmol} \mathrm{m}^{-3}$ $\mathrm{NaCl}$ 溶液中での $V^{\prime}{ }_{\text {pit }}$ が約 $-200 \mathrm{mV}$ ) ではほとんど 孔食発生が抑制されない。一方，あらかじめ $298 \mathrm{~K}$ で 分極し昇温すると, $T^{\prime}{ }_{\text {pit }}$ は電位 b $(200 \mathrm{mV})$ で最も低 くなるが，さらに電位を貴にすると（a）逆に $T^{\prime}{ }_{\text {pit }}$ は 高くなる。このように，硝酸イオンの孔食抑制作用に は，特異な電位依存性が存在する。このような傾向は, 窒素を固溶したステンレス鋼に対する Fig. 2 には見い だせなかった。

\section{2 固溶モリブデンとモリブデン酸イオンの作用の 比較}

Fig. 4 は, 窒素を固溶しない 316 ステンレス鋼（以
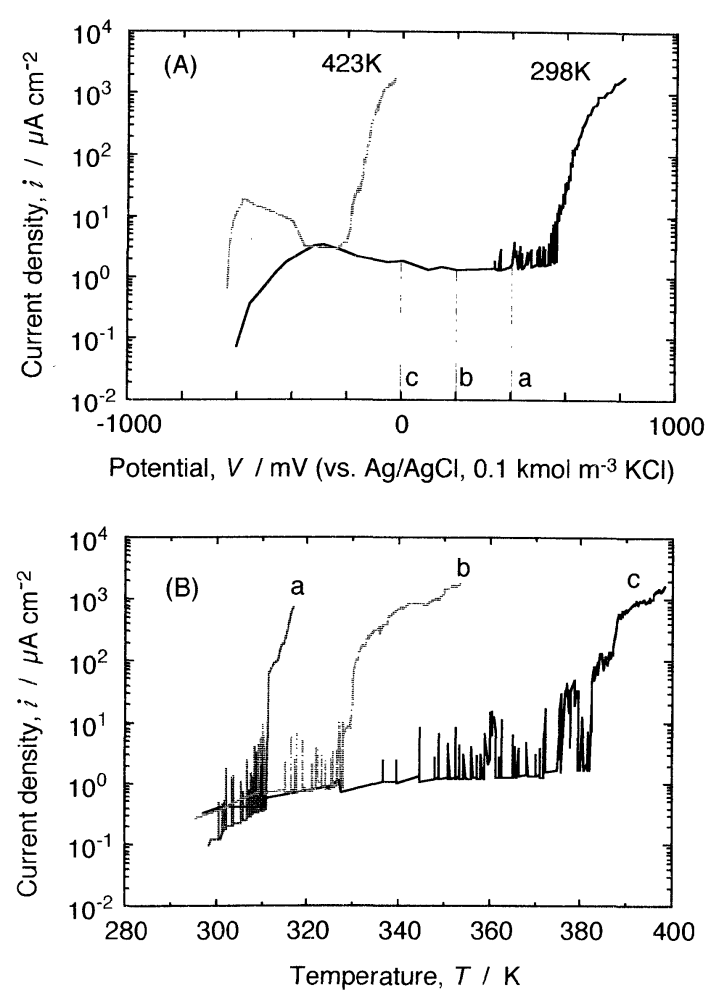

Fig.2 (A) Anodic polarization curves at constant temperatures and (B) current densitytemperature curves at constant potentials (a through c) for $304 \mathrm{~N}$ specimen in $0.1 \mathrm{kmol}$ $\mathrm{m}^{-3} \mathrm{NaCl}$.

下 316 鋼）に対し，温度の関数として測定した電位-電 流曲線（A）と，電位の関数として測定した温度-電流 曲線（B）を示している。同様の測定を, 304 鋼に対し， $0.1 \mathrm{kmol} \mathrm{m}{ }^{-3} \mathrm{NaCl}+0.02 \mathrm{kmol} \mathrm{m}{ }^{-3} \mathrm{Na}_{2} \mathrm{MoO}_{4}$ 溶液 中で測定した結果を Fig. 5 に示す。 $0.1 \mathrm{kmol} \mathrm{m}^{-3}$ $\mathrm{NaCl}$ 溶液中における 304 鋼に対する $V^{\prime}$ pit $(F i g .1)$ と, Fig. 4 および 5 における $V^{\prime}{ }_{\text {pit }}$ の差を $\Delta V^{\prime}$ pit とする と, 316 鋼に対する $\Delta V^{\prime}{ }_{\text {pit }}$ は, $298 \mathrm{~K}$ では $90 \mathrm{mV}$ 程度 であったが， $423 \mathrm{~K}$ では約 $170 \mathrm{mV}$ に広がった。同様 に, $0.1 \mathrm{kmol} \mathrm{m}{ }^{-3} \mathrm{NaCl}+0.02 \mathrm{kmol} \mathrm{m}^{-3} \mathrm{Na}_{2} \mathrm{MoO}_{4}$ 溶液中でも， $\Delta V^{\prime}$ pit は温度とともに大きくなった。こ のように，ステンレス鋼中のモリブデンは，溶液中にモ リブデン酸イオンが存在する場合と類似の $V^{\prime}{ }_{\mathrm{pit}}$ の温度 依存性を与えた。また, 316 鋼に対する $T^{\prime}{ }_{\mathrm{pit}}$ と 304 鋼 に対する $0.1 \mathrm{kmol} \mathrm{m}^{-3} \mathrm{NaCl}+0.02 \mathrm{kmol} \mathrm{m}^{-3}$ $\mathrm{Na}_{2} \mathrm{MoO}_{4}$ 溶液中での $T^{\prime}{ }_{\mathrm{pit}}$ も, 類似の電位依存性を示 した。

\section{3 窒素種とモリブデン種とが同時に存在する場合}

Fig. 6 および 7 は，それぞれ $0.1 \mathrm{kmol} \mathrm{m}^{-3} \mathrm{NaCl}+$ $0.02 \mathrm{kmol} \mathrm{m}^{-3} \mathrm{NaNO}_{3}+0.02 \mathrm{kmol} \mathrm{m}{ }^{-3} \mathrm{Na}_{2} \mathrm{MoO}_{4}$ 

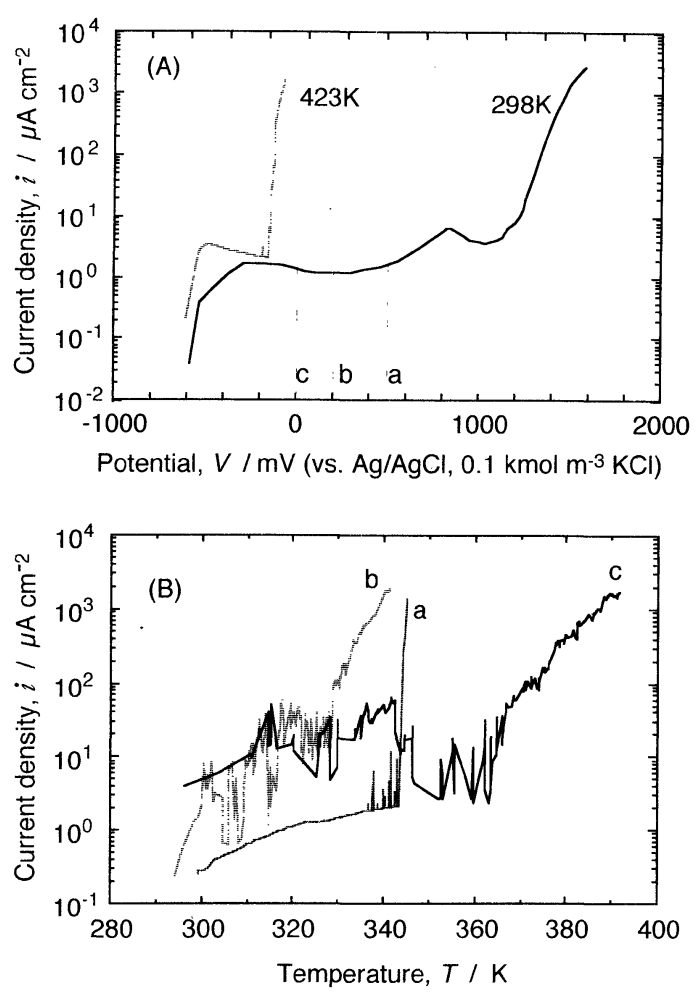

Fig.3 (A) Anodic polarization curves at constant temperatures and (B) current densitytemperature curves at constant potentials (a through c) for 304 specimen in $0.1 \mathrm{kmol}$ $\mathrm{m}^{-3} \mathrm{NaCl}+0.02 \mathrm{kmol} \mathrm{m}^{-3} \mathrm{NaNO}_{3}$.

溶液中における 304 鋼および $0.1 \mathrm{kmol} \mathrm{m}^{-3} \mathrm{NaCl}$ 溶液 中における窒素を固溶した SUS 316 ステンレス鋼（以 下 $316 \mathrm{~N}$ 鋼) に対し, 温度の関数として測定した電位電流曲線と, 電位の関数として測定した温度-電流曲線 を示している。硝酸イオンとモリブデン酸イオンとを同 時に用いた Fig. 6 においては, 硝酸イオンのみを使用 した Fig. 3 と比較すると， $423 \mathrm{~K}$ における孔食電位が 貴にシフトし，モリブデン酸イオンのみを使用した Fig. 5 と比較すると, $298 \mathrm{~K}$ における孔食電位が貴にシ フトしたことがわかる。すなわち， $298 \mathrm{~K}$ ではモリブデ ン酸イオンは有効に作用しないが，もともと $V^{\prime}$ pit が比 較的高いため, 硝酸イオンがさらに有効な孔食抑制作用 を発揮できる。一方, 温度が高くなると, $V^{\prime}{ }_{\text {pit }}$ が卑に なるため，硝酸イオンの抑制効果が期待できなくなる が，逆にここではモリブデン酸イオンの相対的な孔食抑 制作用が高くなる。結果として，Fig. 6 では両者の作 用が補償しあった結果, 室温から高温まで高い孔食抑制 効果が発現されている。同様のことは, 温度-電流曲線 についてもいえる。すなわち，Fig.5（B）では，電位 が高くなると著しく $T^{\prime}{ }_{\text {pit }}$ が低くなったのに対し, Fig.
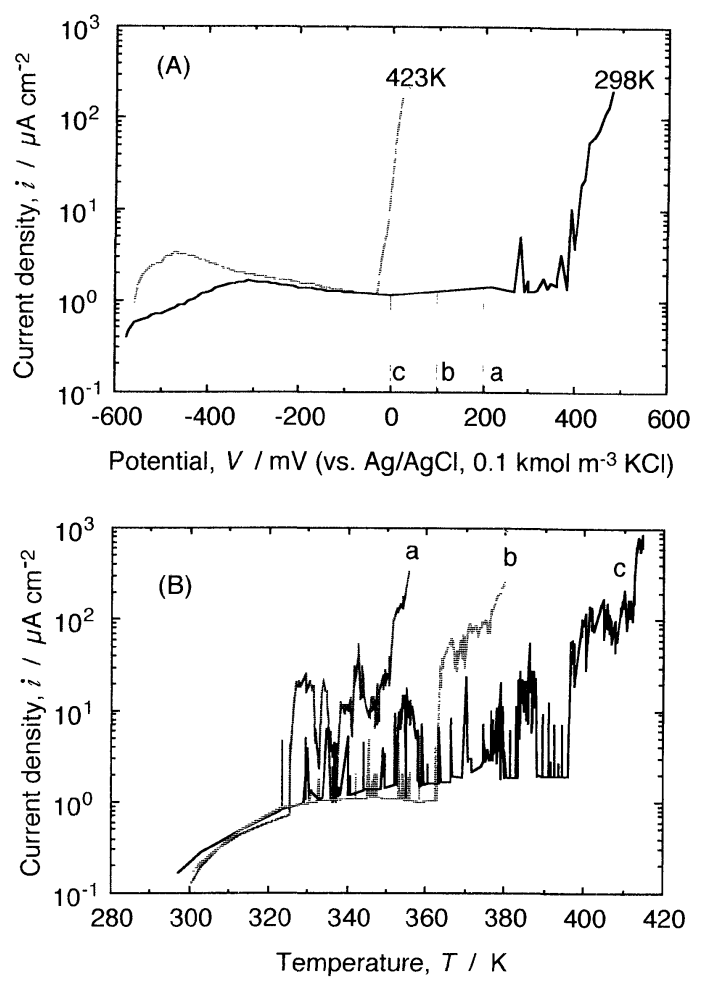

Fig.4 (A) Anodic polarization curves at constant temperatures and (B) current densitytemperature curves at constant potentials (a through c) for 316 specimen in $0.1 \mathrm{kmol}$ $\mathrm{m}^{-3} \mathrm{NaCl}$.

6 （B）では貴な電位ほどむしろ $T^{\prime}{ }_{\mathrm{pit}}$ が高くなってい る。

$316 \mathrm{~N}$ 鋼の場合も， $298 \mathrm{~K}$ におけるアノード分極挙動 は, $304 \mathrm{~N}$ 鋼（Fig. 2) に類似し， $423 \mathrm{~K}$ では 316 鋼 (Fig. 4) と類似している。一方， $T^{\prime}{ }_{\text {pit }}$ は比較的皁な 電位 $(100 \sim 200 \mathrm{mV}$ ) では非常に高く, 優れた耐孔食 性を示したが，Fig. 2（B）あるいはFig.6（B）にみ られるような, 硝酸イオン存在下に特有の高電位で $T^{\prime}{ }_{\text {pit }}$ が高くなる現象は観察されなかった。

\section{4. 考察}

Fig. 1〜7（A）に示した電位-電流曲線から求めた

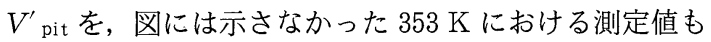
含めて, 温度の関数として Fig. 8 に, また Fig. 1〜7 （B）に示した温度-電流曲線から求めた $T^{\prime}{ }_{\mathrm{pit}}$ を, 図示 しなかった測定值も含めて電位の関数として Fig. 9 に 整理した。

\section{1 固溶窒素と硝酸イオンの作用}

Fig. 8 において, $0.1 \mathrm{kmol} \mathrm{m}^{-3} \mathrm{NaCl}$ 溶液中におけ る 304 鋼に対する $V^{\prime}$ pit（線(1)）を基準にとり，これ 


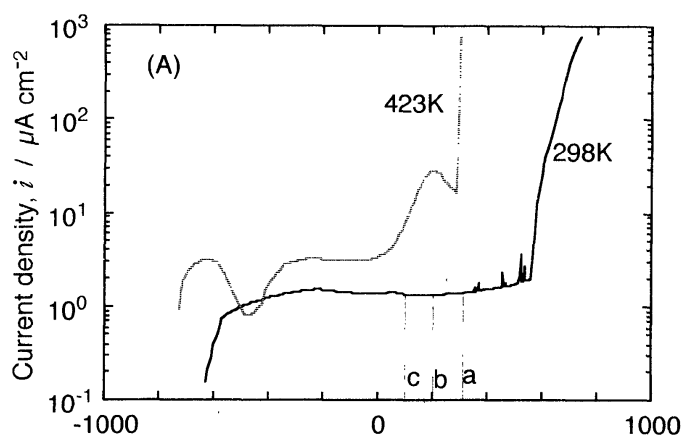

Potential, $V / \mathrm{mV}$ (vs. Ag/AgCl, $0.1 \mathrm{kmol} \mathrm{m}^{-3} \mathrm{KCl}$ )

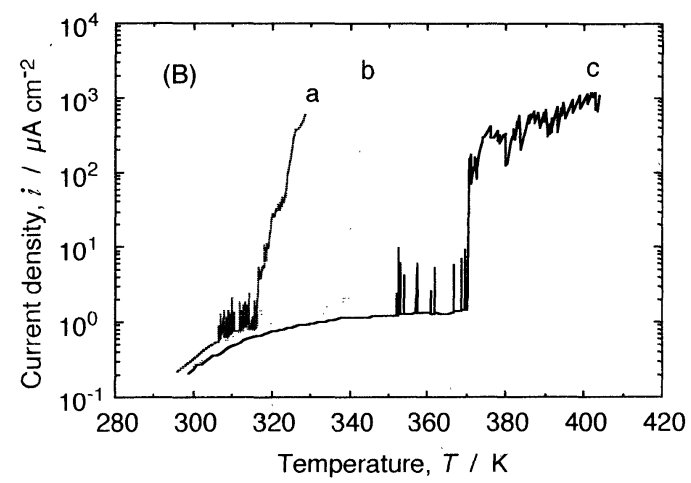

Fig.5 (A) Anodic polarization curves at constant temperatures and (B) current densitytemperature curves at constant potentials (a through c) for 304 specimen in $0.1 \mathrm{kmol}$ $\mathrm{m}^{-3} \mathrm{NaCl}+0.02 \mathrm{kmol} \mathrm{m}^{-3} \mathrm{Na}_{2} \mathrm{MoO}_{4}$.

から $V_{\text {pit }}^{\prime}$ がどれだけ貴にシフトしたか $\left(\Delta V_{\text {pit }}^{\prime}\right)$ を温 度の関数として比較してみると, 硝酸イオン存在下では $298 \mathrm{~K}$ における $\Delta V^{\prime}{ }_{\text {pit }}$ が極めて大きいが, 高温では $\Delta V^{\prime}$ pit が極端に小さくなる（線(3))。これは, すでに 報告している7 のではなく, 高温では硝酸イオンがほとんど作用できな い電位域まで $V^{\prime}{ }_{\text {pit }}$ が卑にシフトするためである。これ は, Fig. 9 において線(3)および(6)の $T^{\prime}{ }_{\text {pit }}$ が高電位域 で高くなることから明らかである。

ステンレス鋼中に固溶した窒素が，孔食を多少なり抑 制することは, Fig. 8 および 9 中の線 (2) と (1) および (7) と (4) との比較から明らかである。ところで Fig. 8 中, 線 (2)および(3)の $\Delta V^{\prime}{ }_{\text {pit }}$ が高温でほとんど 0 になっ ており, 固溶窒素之溶液中の硝酸イオンの孔食抑制作用 に対する温度の影響は類似している。しかし $T^{\prime}{ }^{p}$ it で比 較すると, 硝酸イオンの場合は, Fig. 9 (線(3), (6)) に示されるように, 高電位で $T^{\prime}{ }{ }_{\mathrm{pit}}$ が高くなるが, 固溶 窒素を含むステンレス鋼（線(2)，(7)）ではこのような 現象はみられなかった。

固溶窒素が孔食を抑制することは, 多くの研究者に

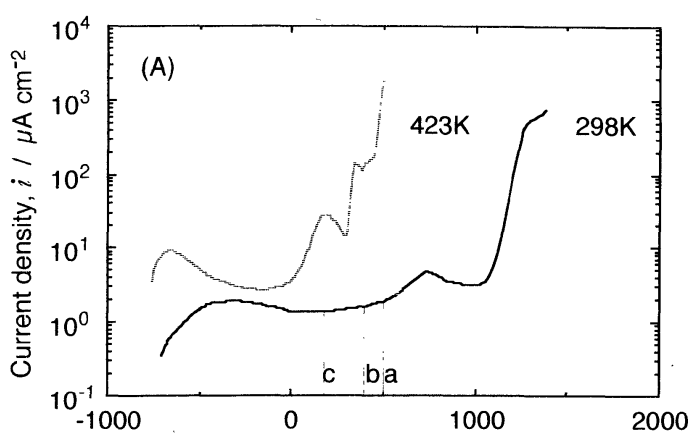

Potential, $V / \mathrm{mV}$ (vs. Ag/AgCl, $0.1 \mathrm{kmol} \mathrm{m}^{-3} \mathrm{KCl}$ )

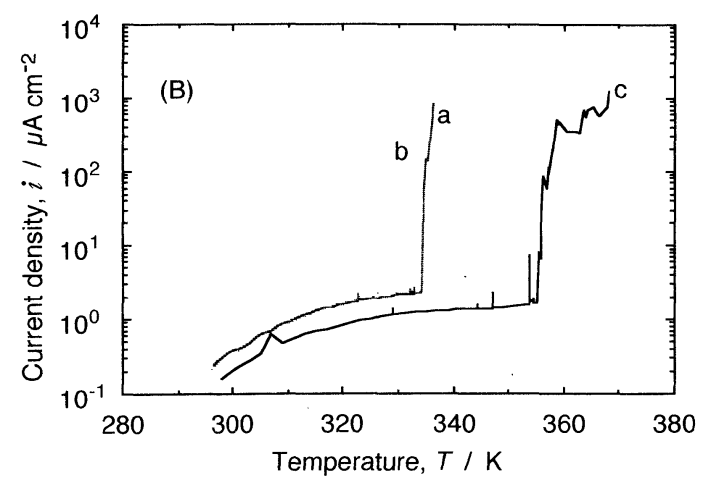

Fig.6 (A) Anodic polarization curves at constant temperatures and (B) current densitytemperature curves at constant potentials (a through c) for 304 specimen in $0.1 \mathrm{kmol}$ $\mathrm{m}^{-3} \mathrm{NaCl}+0.02 \mathrm{kmol} \mathrm{m} \mathrm{m}^{-3} \mathrm{NaNO}_{3}+0.02$ $\mathrm{kmol} \mathrm{m} \mathrm{Na}_{2} \mathrm{MoO}_{4}$.

よって認められているが，その抑制機構についてはいま

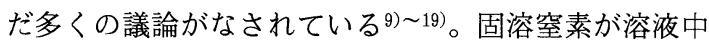
に溶解して生成する化学種には, これまで $\mathrm{NH}_{4}{ }^{+}$2), 12), 17)

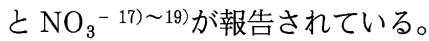

$$
\begin{aligned}
& \mathrm{N}+4 \mathrm{H}^{+}+3 \mathrm{e}^{-} \longrightarrow \mathrm{NH}_{4}{ }^{+} \\
& \mathrm{N}+3 \mathrm{H}_{2} \mathrm{O} \longrightarrow \mathrm{NO}_{3}{ }^{-}+6 \mathrm{H}^{+}+5 \mathrm{e}^{-}
\end{aligned}
$$

固溶窒素が溶解する過程で孔食の発生あるいは成長を 抑制すると仮定すると，式(1)が水素イオン消費反応で あることから，局部的な $\mathrm{pH}$ 低下を緩衝すると期待でき る2)。ここではこれを直接支持する証拠はないが, Fig. 9 において, 熱力学的に $\mathrm{NO}_{3}$-が生成しないと考え られる $0 \mathrm{mV}$ でも, 窒素固溶化によって $T^{\prime}{ }_{\mathrm{pit}}$ が高く なっていることから, 式(1)の効果の可能性が高いと考 えられる。

一方, 固溶窒素が溶解して生成した化学種が孔食を抑 制すると仮定すると，式(2)自体は水素イオン生成反応 ではあるが，生成した硝酸イオンの孔食抑制作用が期待 される ${ }^{18)}$ 。本研究は, 溶液中に硝酸イオンが存在する 場合に観察される $T^{\prime}{ }_{\mathrm{pit}}$ の特異な電位依存性が, 窒素を 

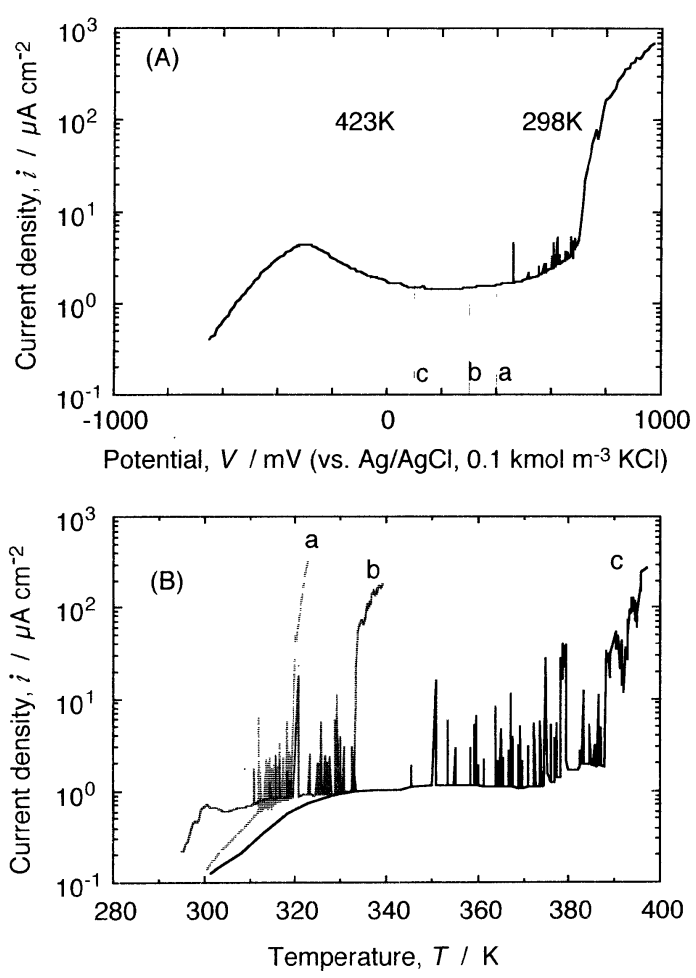

Fig.7 (A) Anodic polarization curves at constant temperatures and (B) current densitytemperature curves at constant potentials (a through c) for $316 \mathrm{~N}$ specimen in $0.1 \mathrm{kmol}$ $\mathrm{m}^{-3} \mathrm{NaCl}$.

固溶したステンレス鋼においても観察されるか否かに注 目して実験を行った。その結果， $T^{\prime}$ pit が電位とともに 貴になる傾向は観察されていない。このことから, 窒素 添加ステンレス鋼において, 高電位域であっても硝酸イ オンが孔食抑制の中心的役割をしているという仮定を直 接支持することはできなかった。なお，溶液に添加した 硝酸イオンの濃度は $0.02 \mathrm{kmol} \mathrm{m}^{-3}$ なのに対し, 窒素

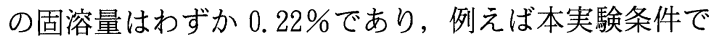
ある $160 \mathrm{~cm}^{3}$ の溶液中に地金 $1 \mathrm{mg}$ が均一に溶解して も, 生成する $\mathrm{NO}_{3}{ }^{-}$の濃度は $10^{-6} \mathrm{kmol} \mathrm{m}^{-3}$ 程度にし かならない。したがって $304 \mathrm{~N}$ 鋼の $T^{\prime}$ pit の電位依存 性が $\mathrm{NO}_{3}{ }^{-}$添加の場合と類似しないのは, $\left[\mathrm{Cl}^{-}\right] /$ $\left[\mathrm{NO}_{3}{ }^{-}\right]$比の影響も考えられる。このため, $\mathrm{NaCl}$ 濃度 を $0.005 \mathrm{kmol} \mathrm{m}^{-3}$ まで低くした溶液中でも $304 \mathrm{~N}$ 鋼の $T^{\prime}{ }_{\text {pit }}$ を電位の関数として測定してみたが，これまでの ところ $T^{\prime}{ }_{\text {pit }}$ が電位とともに高くなる現象は観察されて いない。

なお, 孔食抑制に対する窒素の作用については, 溶液 側の因子以外に, 皮膜中あるいは皮膜直下での窒素の濃 縮などによって溶解が抑制される可能性も報告されてい

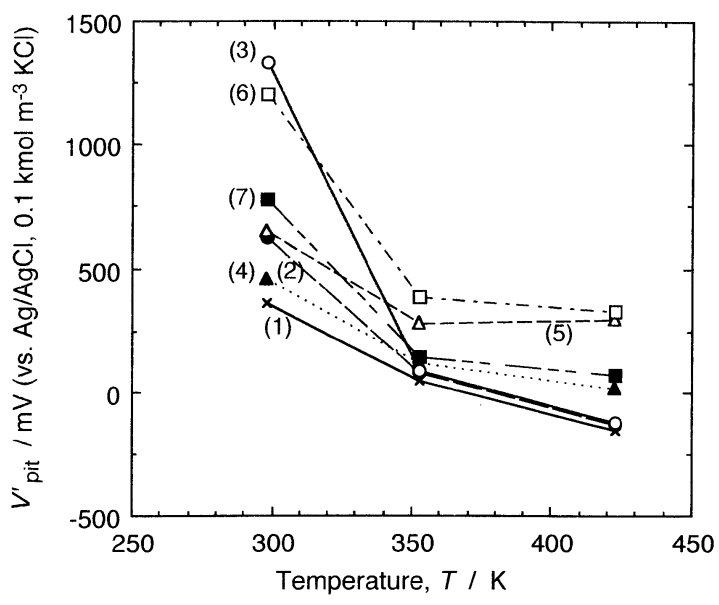

Fig.8 Effect of temperature on pitting potential for (1) 304 specimen in $0.1 \mathrm{kmol} \mathrm{m}^{-3} \mathrm{NaCl}$, (2) $304 \mathrm{~N}$ specimen in $0.1 \mathrm{kmol} \mathrm{m}^{-3} \mathrm{NaCl}$, (3) 304 specimen in $0.1 \mathrm{kmol} \mathrm{m}^{-3} \mathrm{NaCl}+\mathrm{NaNO}_{3}$, (4) 316 specimen in $0.1 \mathrm{kmol} \mathrm{m}^{-3} \mathrm{NaCl}$, (5) 304 specimen in $0.1 \mathrm{kmol} \mathrm{m}^{-3} \mathrm{NaCl}+0.02 \mathrm{kmol}$ $\mathrm{m}^{-3} \mathrm{Na}_{2} \mathrm{MoO}_{4}$, (6) 304 specimen in $0.1 \mathrm{kmol}$ $\mathrm{m}^{-3} \mathrm{NaCl}+0.02 \mathrm{kmol} \mathrm{m}^{-3} \mathrm{NaNO}_{3}+0.02 \mathrm{kmol}$ $\mathrm{m}^{-3} \mathrm{Na}_{2} \mathrm{MoO}_{4}$ and (7) $316 \mathrm{~N}$ specimen in 0.1 $\mathrm{kmol} \mathrm{m} \mathrm{m}^{-3} \mathrm{NaCl}$.

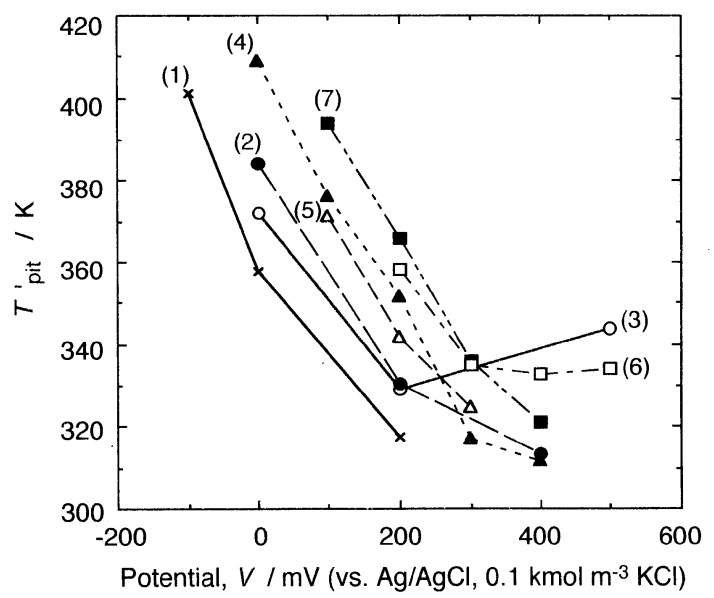

Fig.9 Effect of applied potential on pitting temperature for (1) 304 specimen in $0.1 \mathrm{kmol}$ $\mathrm{m}^{-3} \mathrm{NaCl}$, (2) $304 \mathrm{~N}$ specimen in $0.1 \mathrm{kmol}$ $\mathrm{m}^{-3} \mathrm{NaCl}$, (3) 304 specimen in $0.1 \mathrm{kmol}$ $\mathrm{m}^{-3} \mathrm{NaCl}+\mathrm{NaNO}_{3}$, (4) 316 specimen in $0.1 \mathrm{kmol} \mathrm{m}^{-3} \mathrm{NaCl}$, (5) 304 specimen in $0.1 \mathrm{kmol} \mathrm{m} \mathrm{m}^{-3} \mathrm{NaCl}+0.02 \mathrm{kmol} \mathrm{m}^{-3} \mathrm{Na}_{2}$ $\mathrm{MoO}_{4}$, (6) 304 specimen in $0.1 \mathrm{kmol} \mathrm{m} \mathrm{m}^{-3}$ $\mathrm{NaCl}+0.02 \mathrm{kmol} \mathrm{m}{ }^{-3} \mathrm{NaNO}_{3}+0.02 \mathrm{kmol}$ $\mathrm{m}^{-3} \mathrm{Na}_{2} \mathrm{MoO}_{4}$ and (7) $316 \mathrm{~N}$ specimen in $0.1 \mathrm{kmol} \mathrm{m}^{-3} \mathrm{NaCl}$. 
$ろ^{10), 11), 13), 14)}$

\section{2 固溶モリブデンとモリブデン酸イオンの作用}

Fig. 8 において，曲線(5)および(6)の $\Delta V^{\prime}$ pit は明ら かに温度と共に大きくなった。これは高温ほど，モリブ デン酸イオンが関与する孔食抑制反応が促進されること を意味している。しかしこれは酸素を除いた溶液中, 自 然電位で昇温した場合であり，a〜cの所定電位に保持 したまま昇温すると，Fig. 5 にみられるように，423 K における $V^{\prime}$ pit より卑な電位でさえ， $423 \mathrm{~K}$ に達する前 に孔食が生じる場合がある。これは，モリブデン酸イオ ンを含む溶液中では自然浸漬状態で昇温した後に耐孔食 性に優れた皮膜が形成されるためと推定される ${ }^{7)}$ が, 逆 にこのようにして高温に昇温してから測定されたアノー ド分極曲線から期待される耐食性は, 昇温過程では必ず しも発現されないということでもある。

ステンレス鋼中にモリブデンを固溶した場合（Fig. 8 の線 (4), (7)) の $\Delta V^{\prime}{ }_{\text {pit }}$ の温度依存性は, 溶液中にモ リブデン酸イオンを添加した場合と類似しており, 線 (7) では $298 \mathrm{~K}$ で固溶窒素の影響もみられるが, $353 \mathrm{~K}$ と $423 \mathrm{~K}$ を比較すると, 明らかに $423 \mathrm{~K}$ で $\Delta V^{\prime}{ }_{\text {pit }}$ が増加 している。しかし, 鋼中にモリブデンを添加した場合は,

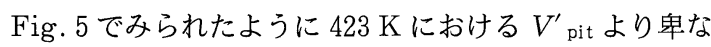
電位で昇温中に孔食が発生することはなかった。Fig. 8 に示した自然浸漬状態で昇温した場合には, 総じて溶 液中にモリブデン酸イオンを含む場合（線(5), (6)）に 最も貴な $V^{\prime}{ }_{\text {pit }}$ が得られたのに対し，分極下で昇温した Fig. 9 では, 固溶モリブデンを含む場合（線 (4), (7)） の方が高い $T^{\prime}{ }_{\text {pit }}$ を与えた。あらかじめアノード分極す ると, 固溶モリブデンは酸化されて不動態皮膜中に取り 込まれるが，溶液中に存在するモリブデン酸イオンが皮 膜に取り込まれる反応は, アノード分極下ではなく, 酸 素を除いた溶液中，非常に卑な自然電位下で進行しやす いためと考えられる。

\section{3 室素種とモリブデン種との混合作用}

これまで述べてきたように，硝酸イオンは貴な電位で 高い孔食抑制効果を発現するが， $V^{\prime}{ }_{\text {pit }}$ が卑になる高温 ではほとんど抑制効果を示さない。一方，モリブデン酸 イオンは高温で優れた孔食抑制効果を発現するが, 室温 付近では十分な抑制効果を発揮しない。したがって, 両 者を混合すれば, それぞれの欠点が補われて, 室温から 高温まで理想的な孔食抑制効果が期待できる。Fig. 8 の線(6)では, まだモリブデン酸イオンの濃度が塩化物 イオン濃度に対して十分でないが, 溶液中の硝酸イオン とモリブデン酸イオン濃度を適切にすれば，高温でも， 400 500 mV 程度までの孔食発生をモリブデン酸イオ ンが抑制し, それ以上の電位での孔食発生を硝酸イオン が抑制するといった効果を期待することができる。
Fig. 8 において, $304 \mathrm{~N}$ 鋼に対する $\Delta V^{\prime}{ }_{\text {pit }}$ が $298 \mathrm{~K}$ で 最も大きく, 316 鋼に対する $\Delta V^{\prime}{ }_{\text {pit }}$ が $423 \mathrm{~K}$ で最も大 きかったことから, 窒素とモリブデンの作用を合わせ持 つと期待できる $316 \mathrm{~N}$ 鋼の $\Delta V^{\prime}{ }_{\text {pit }}$ が, 室温から高温ま でほぼ一様であったことは理にかなっている。特にあら かじめ分極下にある場合 (Fig. 9), $300 \mathrm{mV}$ 以下の電 位域では， $316 \mathrm{~N}$ 鋼の $T^{\prime}{ }_{\text {pit }}$ (線 (7)) が他のいずれの条 件よりも高かったことは, $316 \mathrm{~N}$ 鋼が酸化雾囲気中で高 い耐孔食性を発現することを意味しており，注目に值す る。しかし, 固溶窒素には固溶量自体に上限があること と, 高電位側で必ずしも硝酸イオンと同様の特異な孔食 抑制効果が認められていないので, $0.1 \mathrm{kmol} \mathrm{m}^{-3} \mathrm{NaCl}$ のような高腐食性の溶液中では, すべての温度で孔食発 生を完全に抑制することはできない。

\section{5. 結論}

オーステナイト系ステンレス鋼の耐孔食性に及ぼす固 溶窒素およびモリブデンの影響を, 溶液中に加えた硝酸 イオンおよびモリブデン酸イオンの影響と比較して検討 し, 以下の結論を得た。

（1）一般に固溶した窒素は, 孔食電位 $\left(V^{\prime}{ }_{\mathrm{pit}}\right)$ およ び孔食温度 $\left(T^{\prime}{ }_{\text {pit }}\right)$ を高くし，孔食を抑制する効果を 示す。しかし, 窒素のみを固溶したステンレス鋼および, 溶液中に硝酸イオンのみを加えた場合は, 高温ではほと んど孔食抑制効果が発現されなかった。一方， $T^{\prime}{ }^{\prime}{ }^{2}$ は, 硝酸イオン存在下では高電位域で電位とともに高く なるという特徵があるが, 窒素を固溶したステンレス鋼 ではこのような傾向は観察されなかった。

（2） ステンレス鋼中に固溶したモリブデンおよび溶 液中のモリブデン酸イオンの孔食抑制効果は, どちらも 高温ほど高くなった。溶液中のモリブデン酸イオンの孔 食抑制作用は, あらかじめアノード分極下にあると, 昇 温過程では十分発現されないが, 固溶モリブデンの孔食 抑制効果は, アノード分極下での昇温試験においても発 現された。

（3）溶液中に硝酸イオンとモリブデン酸イオンを同 時に加えると，それぞれ貴な電位と高温で特徴的な優れ た孔食抑制効果を同時に得ることができる。ステンレス 鋼中に窒素とモリブデンを固溶した場合も，それぞれ単 独に固溶した場合の特徴が同時に発現され，バランスの とれた耐食性材料となる。

\section{謝 辞}

本研究に協力いただきました本学斎藤四郎技術官に感 謝申し上げます。また, 本研究に使用した試験片は,「高 窒素ステンレス鋼の耐食性と材料科学」分科会を通し, 住友金属工業(株)，日本金属工業(株)および日本治金 
（株)のご好意により作製いただきました。

(Manuscript received February 27, 1998; in final form April 30,1998)

\section{参 考 文 献}

1) A. T. Sedriks: "Corrosion of Stainless Steels", p.112, John Wiley \& Sons (1996).

2 ) K. Osozawa, N. Okato, Y. Fukase and K. Yokota: 防食技術, 24, 1 (1975).

3 ) K. Sugimoto and Y. Sawada: Corrosion, 32, 347 (1976).

4) 遅沢浩一郎 : 熱処理, 36, 206 (1996).

5) P. R. Levey and A. Bennekom: Corrosion, 51, 911 (1995).

$6)$ H.P.Leckie and H.H.Uhlig: J. Electrochem. Soc., 113, 1262 (1966).

7) H. Yashiro, A. Oyama and K. Tanno: Corrosion, 53, 290 (1997).

8 ) H. Yashiro, K. Tanno, H. Hanayama and A. Miura, Corrosion, 46, 727 (1990).

9 ) R. Bandy and D. V. Rooyen : Corrosion, 41,
228 (1985).

10) R.C.Newman and T.Shahrabi: Corros. Sci., 27, 827 (1987).

11) Y. Lu, R. Bandy, C. R. Clayton and R. C. Newman: J. Electrochem. Soc., 130, 1774 (1983).

12) G. C. Palit, V. Kain and H. S. Gadiyar: Corrosion, 49, 977 (1993).

13) A.S.Vanini, J.-P.Audouard and P.Marcus: Corros. Sci., 36, 1825 (1994).

14) I. Olefjord and L. Wegrelius, Corros. Sci., 38, 1203 (1996).

15) S.J.Pawel, E.E.Stansbury and C.D.Lundin: Corrosion, 45, 125 (1987).

16) S. Azuma, H. Miyuki and T. Kudo: ISIJ Int., 36, 793 (1996).

17）小森唯志, 中田潮雄 : 第 39 回腐食防食討論会予 稿集, p.353 (1992).

18）飯住健爾, 川野謙一, 鈴木隆三，友田 陽，松島 正博, 田中 勝, 半谷文雄 : 第 38 回腐食防食討 論会予稿集, p.71 (1991).

19) T. Misawa and H. Tanabe: ISIJ Int., 36, 787 (1996). 